\title{
Hubungan Jumlah Leukosit serta Kadar Cluster of Differentiation-4 dengan Derajat Keparahan Pneumonia pada Anak dengan Infeksi Human Immmunodeficiency Virus
}

I Nyoman Supadma, Putu Siadi Purniti, Ida Bagus Subanada, Ayu Setyorini Mestika Mayangsari, Ketut Dewi Kumara Wati, Komang Ayu Witarini

Bagian Ilmu Kesehatan Anak Fakultas Kedokteran Universitas Udayana/RSUP Sanglah, Denpasar

Latar belakang. Pneumonia merupakan penyebab utama morbiditas dan mortalitas pada anak usia di bawah 5 tahun di seluruh dunia, terutama pada infeksi human immunodeficiency virus (HIV). Parameter yang mudah diukur dan dikerjakan diperlukan untuk memprediksi derajat keparahan pneumonia pada anak dengan HIV.

Tujuan. Mengetahui hubungan jumlah leukosit dan kadar CD4 dengan derajat keparahan pneumonia pada anak dengan infeksi HIV. Metode. Penelitian analitik dengan desain potong lintang, dilibatkan 42 anak HIV dengan pneumonia berat dan sangat berat. Pemeriksaan penunjang yang rutin dikerjakan adalah darah lengkap dan kadar CD4.

Hasil. Nilai median (minimal-maksimal) kadar CD4 pneumonia sangat berat lebih rendah $[19,5(12,5-26,0)] \%$ dibandingkan dengan pneumonia berat $[35,3(14,0-56,5)] \%$. Analisis bivariat menunjukkan derajat keparahan pneumonia tidak dipengaruhi oleh jumlah leukosit [RO 0,63 (IK 95\% 0,09 sampai 4,23), p=0,63], tetapi dipengaruhi oleh kadar CD4 [RO 0,10 (IK 95\% 0,02 sampai 0,46), $\mathrm{p}=0,01]$.

Kesimpulan. Kadar CD4 berhubungan dengan derajat keparahan pneumonia pada anak dengan infeksi HIV. Sari Pediatri 2017;19(1):36-40

Kata kunci: jumlah leukosit, kadar CD4, derajat pneumonia, infeksi HIV

\section{Relationships of Leukocytes Count and Cluster of Differentiation-4 Levels with of Severity of Pneumonia in Children with Human Immmunodeficiency Virus Infection}

I Nyoman Supadma, Putu Siadi Purniti, Ida Bagus Subanada, Ayu Setyorini Mestika Mayangsari, Ketut Dewi Kumara Wati, Komang Ayu Witarini

Background. Pneumonia leads cause of morbidity and mortality in children aged under 5 years worldwide, mainly in human immunodeficiency virus (HIV). Parameters are easily measured and worked needed to predict the severity of pneumonia in children with HIV.

Objective. This study determines the relationship of leukocyte count and CD4 levels with severity of pneumonia in children with HIV infection.

Method. This research used analytical study with cross-sectional design. Involving 42 children with HIV with severe and very severe pneumonia. The routine laboratory examination in this children with HIV were whole blood count and CD4 levels.

Results. Very severe pneumonia has a lower CD4 median value (minimum-maximum) [19.5 (12.5 to 26.0)]\% than the CD4 median cell count at severe pneumonia $[35.3(14.0$ to 56,5$)] \%$. The bivariate analysis shows the severity of the pneumonia isn't influenced by the leukocytes count [RO 0.63 (95\% CI 0.09 to 4.23), $\mathrm{p}=0.63$ ] but it's influenced by levels of CD4 [RO 0.10 (CI $95 \% 0.02$ to $0.46), \mathrm{p}=0.01]$.

Conclusion. There is relationship between CD4 levels and severity of pneumonia in children with HIV infection. Sari Pediatri 2017;19(1):36-40

Keywords: leukocyte count, CD4 count, severity of pneumonia, HIV infection

Alamat korespondensi: Dr. I Nyoman Supadma. Bagian Ilmu Kesehatan Anak Fakultas Kedokteran Universitas Udayana/RSUP Sanglah. Jln Jl. Pulau Nias Denpasar-Bali. Email: inyomansupadma@gmail.com 
$\mathrm{P}$ neumonia merupakan penyebab utama morbiditas dan mortalitas pada anak usia di bawah 5 tahun di seluruh dunia, termasuk pada infeksi human immune deficiency virus (HIV). Virus HIV merupakan retrovirus yang menginfeksi dan menghancurkan fungsi sel-sel imunitas manusia, terutama cluster of differentiation 4 (CD4) sel T, makrofag, dan komponen utama sistem imunitas selular tubuh lainnya. ${ }^{1,2}$

Acquired immune deficiency syndrome (AIDS) merupakan tahap infeksi HIV yang terjadi ketika sistem imunitas sangat menurun sehingga rentan mengalami infeksi oportunistis. Anak didiagnosis AIDS jika menderita satu atau lebih penyakit oportunistis, terlepas dari jumlah CD4. Badan kesehatan dunia WHO melaporkan peningkatan angka kematian pneumonia yang disertai HIV. Pada tahun 2013, persentase angka kematian pneumonia yang disertai HIV anak usia di bawah 5 tahun di negara berkembang dan Afrika adalah 99\% dan 93\%. Angka tersebut jauh di atas angka kematian karena pneumonia tanpa HIV. Diperkirakan, di negara berkembang seperti di Indonesia, persentase angka kematian pneumonia tanpa HIV 28\%-34\% pada anak usia di bawah 5 tahun. ${ }^{1-3}$

Dari semua kasus pneumonia, 20\% dengan disertai infeksi HIV.5 Pneumocystis carinii pneumoniae (PCP) merupakan salah satu pneumonia berat pada individu dengan sistem imun yang buruk karena HIV. ${ }^{4,5}$ Anak dengan HIV dan pneumonia lebih mudah mengalami penyakit berat lain dibandingkan dengan tanpa pneumonia. ${ }^{78}$ Sampai saat ini, belum ada parameter yang mudah diukur dan dikerjakan untuk mengetahui derajat keparahan infeksi pneumonia pada anak dengan infeksi HIV. Pemeriksaan laboratorium rutin adalah leukosit dan kadar CD4. Berdasarkan hal tersebut, peneliti ingin mengetahui hubungan antara jumlah leukosit dan kadar CD4 dengan derajat keparahan pneumonia pada anak dengan infeksi HIV.

\section{Metode}

Penelitian potong lintang dilakukan di Sub Bagian Respirologi SMF Ilmu Kesehatan Anak FK UNUD/ RSUP Sanglah. Subjek adalah anak yang menderita pneumonia dengan infeksi HIV/AIDS yang dirawat di RSUP Sanglah Denpasar bulan Januari tahun 2012 sampai bulan Desember tahun 2015 berdasarkan data dari rekam medis.

Semua subjek pneumonia dengan infeksi
HIV/AIDS berusia 0-12 tahun diikutsertakan ke dalam penelitian. Sampel dipilih secara konsekutif menggunakan rumus untuk penelitian analitis numerik tidak berpasangan dengan hipotesis satu arah, kesalahan tipe I sebesar 5\%, tipe II 20\%, simpangan baku jumlah leukosit dari kepustakaan adalah $6,6,{ }^{11}$ dan kadar CD4 32,15. ${ }^{18}$ Besar sampel minimal untuk masing-masing kelompok adalah 21 . Kriteria inklusi adalah data rekam medis dari semua subjek berusia 0-12 tahun yang menderita penyakit pneumonia dengan infeksi HIV/AIDS. Data rekam medis yang tidak lengkap dan memiliki penyakit lain selain pneumonia dan HIV/AIDS dimasukkan ke dalam kriteria eksklusi.

Data karakteristik yang diteliti, yaitu jenis kelamin, usia, status gizi, stadium infeksi HIV, derajat pneumonia, jumlah leukosit, kadar CD4, hasil pemeriksaan biakan darah, dan luaran pasien (meninggal atau hidup). Definisi operasional variabel pneumonia berat, jika didapatkan klinis batuk disertai sulit bernapas atau napas cepat disertai retraksi dinding dada. Pada auskultasi didapatkan rales atau suara napas menurun atau suara napas bronkial dan didukung oleh pemeriksaan rontgen dada, status gizi berdasarkan kriteria Waterlow. Status gizi dibedakan menjadi tiga, yaitu gizi baik, kurang, dan buruk. Diagnosis HIV/ AIDS ditegakkan berdasarkan kriteria WHO dengan pembagian stadium klinis 1 (asimtomatik), stadium 2 (ringan), stadium 3 (sedang), dan stadium 4 (berat/ AIDS). Jumlah leukosit adalah jumlah total sel darah putih yang diperiksa saat subjek pertama kali diambil darah, dibedakan menjadi $<10000 \mu \mathrm{L}$ dan $\geq 10000$ $\mu$ L. Kadar CD4 dibedakan menjadi $<25 \%$ dan $\geq 25 \%$. Sementara itu, biakan darah dibedakan menjadi ada atau tidak ada pertumbuhan kuman.

\section{Hasil}

Berdasarkan data dasar subjek penelitian didapatkan nilai median (interquartil range) usia pada kelompok pneumonia sangat berat lebih tinggi, yaitu 105 (14144) bulan dibandingkan kelompok pneumonia berat, yaitu 86 (10-125) bulan. Karakteristik subjek penelitian tertera pada Tabel 1. Analisis bivariat menunjukkan tidak adanya hubungan yang bermakna antara derajat keparahan pneumonia dengan jumlah leukosit [RO 0,63 (IK 95\% 0,09 sampai 4,23), $\mathrm{p}=0,63$ ], tetapi berhubungan dengan kadar CD4 [RO 0,10 (IK 95\% 0,02-0,46), $\mathrm{p}=0,01$ ] (Tabel 2). 
I Nyoman Supadma dkk: Hubungan jumlah leukosit serta kadar CD4 dengan pneumonia pada infeksi HIV

Tabel 1. Karakteristik subjek

\begin{tabular}{lcc}
\hline Variabel & $\begin{array}{c}\text { Pneumonia berat } \\
(\mathrm{n}=21)\end{array}$ & $\begin{array}{c}\text { Pneumonia sangat } \\
\text { berat }(\mathrm{n}=21)\end{array}$ \\
\hline Usia, bulan, median (interquartil range) & $86(10-125)$ & $105(14-144)$ \\
Jenis kelamin, lelaki, $\mathrm{n}$ & 12 & 10 \\
\hline Status gizi, $\mathrm{n}$ & & \\
$\quad$ Baik & 4 & 1 \\
Kurang, & 14 & 14 \\
$\quad$ Buruk & 3 & 6 \\
Stadium infeksi HIV, $\mathrm{n}$ & & \\
$\quad$ Asimtomatik & 3 & 1 \\
Ringan & 11 & 11 \\
Sedang & 5 & 8 \\
$\quad$ Berat & 2 & 8 \\
Biakan darah, tidak ada pertumbuhan & 13 & 1 \\
kuman, $\mathrm{n}$ & 2 & \\
Luaran, hidup, $\mathrm{n}$ & & \\
\hline
\end{tabular}

Tabel 2. Hasil analisis bivariat jumlah leukosit dan kadar CD4 dengan derajat pneumonia

\begin{tabular}{|c|c|c|c|c|c|c|}
\hline & \multicolumn{4}{|c|}{ Derajat pneumonia } & \multirow[t]{3}{*}{ RO (IK 95\%) } & \multirow[t]{3}{*}{$\mathrm{p}$} \\
\hline & \multicolumn{2}{|c|}{ Berat } & \multicolumn{2}{|c|}{ Sangat berat } & & \\
\hline & $\mathrm{n}$ & $\%$ & $\mathrm{n}$ & $\%$ & & \\
\hline \multicolumn{7}{|l|}{ Leukosit } \\
\hline$<10.000$ & 18 & 85,7 & 19 & 90,5 & $0,63(0,09$ sampai 4,23$)$ & 0,63 \\
\hline$\geq 10.000$ & 3 & 14,3 & 2 & 9,5 & & \\
\hline \multicolumn{7}{|c|}{ Kadar CD4 } \\
\hline$<25 \%$ & 8 & 38,1 & 18 & 85,7 & $0,10(0,02$ sampai 0,46$)$ & $0,01^{*}$ \\
\hline \multirow[t]{2}{*}{$\geq 25 \%$} & 13 & 61,9 & 3 & 14,3 & & \\
\hline & 42 & 100,0 & 42 & 100,0 & & \\
\hline
\end{tabular}

\section{Pembahasan}

Sel limfosit $T$ mempunyai protein CD4 pada permukannya yang bekerja sebagai reseptor untuk HIV. Sel CD4, makrofag, serta komponen utama sistem imunitas mengalami kerusakan akibat infeksi HIV. Anak yang terinfeksi HIV mengalami penurunan kadar CD4. Penurunan kadar CD4 merupakan tanda bahwa sistem kekebalan tubuh sedang menurun dan lebih mudah mengalami infeksi pneumonia. ${ }^{1-4}$

Kadar CD4 yang lebih rendah lebih banyak ditemukan pada kelompok pneumonia sangat berat. ${ }^{5,6}$ Hal tersebut sesuai dengan penelitian kami, yaitu kadar CD $4<25 \%$ lebih banyak ditemukan pada kelompok pneumonia sangat berat $(85,7 \%)$. Gejala klinis pasien dengan infeksi HIV dan pneumonia tampak tidak spesifik dan pemeriksaan penunjang yang akurat masih sulit dilakukan. Pemeriksaan penunjang yang masih dikerjakan dan memberikan manfaat di antaranya adalah darah lengkap (jumlah leukosit), pemeriksaan radiologi dada, biakan darah, dan kadar CD4. ${ }^{6,7}$

Infeksi pneumonia meningkat seiring dengan penurunan kadar CD4 pada anak dengan HIV. Penelitian yang dilakukan oleh Chakravart $\mathrm{dkk}^{19}$ melaporkan bahwa jumlah CD4 secara signifikan berkorelasi terbalik dengan infeksi pneumonia. ${ }^{9,19}$ Penelitian kami mendapatkan data bahwa derajat keparahan pneumonia dipengaruhi oleh kadar CD4 yang lebih berat. Semakin parah infeksi pneumonia, semakin turun kadar CD4. Penelitian yang dilakukan 
oleh Singh $\mathrm{dkk}^{18}$ melaporkan data bahwa pneumonia sangat berat mempunyai nilai median (minimalmaksimal) kadar CD4 lebih rendah dibandingkan dengan pada pneumonia berat. Hal tersebut juga membuktikan bahwa penderita pneumonia sangat berat memiliki kadar CD4 yang lebih rendah.

Ballin $\mathrm{dkk}^{13}$ melaporkan bahwa rerata jumlah leukosit yang tinggi ditemukan pada kelompok subjek dengan imunosupresi $[21,018(\mathrm{SB} 10,420) \times 103 \mu \mathrm{L}] \mathrm{di}-$ bandingkan dengan dewasa [12,628 (SB 6,735) x 103 $\mu \mathrm{L}]$. Hoser $\mathrm{dkk}^{11}$ melaporkan bahwa terjadi leukositosis pada pneumonia yang berasal dari infeksi berat seperti sepsis dengan median jumlah leukosit $12,638 \times 103 \mu \mathrm{L}$ dengan rentang antara 8,450 sampai 16,650 x $103 \mu \mathrm{L}$. Penelitian yang dilakukan oleh Furer $\mathrm{dkk}^{14}$ melaporkan bahwa leukositosis ditemukan pada sebagian besar subjek dengan pneumonia, tetapi $21 \%$ subjek pneumonia tidak mengalami leukositosis. Toikka $\mathrm{dkk}^{16}$ melaporkan $17 \%$ subjek dengan pneumonia datang dengan jumlah leukosit yang normal. Penelitian kami mendapatkan data bahwa leukositosis lebih banyak terjadi pada kelompok pneumonia berat dibandingkan dengan kelompok pneumonia sangat berat walaupun tidak berbeda bermakna secara statistik. Hal tersebut terjadi karena leukosit merupakan sistem imunitas yang bersifat tidak spesifik, tidak hanya infeksi paru yang meningkat melainkan infeksi di tempat lain juga memberikan gambaran leukositosis.

Leukositosis dapat terjadi tergantung dari waktu pemeriksaan sejak timbulnya pneumonia. Pada awalnya, tubuh merespon dengan cara mengeluarkan leukosit dalam jumlah yang berlebihan, tetapi apabila terapi tidak adekuat atau progresivitas pneumonia bertambah maka jumlah leukosit akan menurun. ${ }^{18}$ Penelitian kami memiliki beberapa kelemahan, antara lain, penyebab pneumonia tidak dijelaskan secara rinci dan pemeriksaan jumlah leukosit hanya dilakukan pada saat awal datang ke rumah sakit sehingga evaluasi setelah pengobatan tidak dapat dibuktikan. Sebaiknya, diperiksa kadar limfosit $T$ total pada pemeriksaan leukosit yang lebih spesifik untuk infeksi HIV/ AIDS. Riwayat mendapatkan antibiotik sebelumnya tidak dijelaskan. Jenis kuman dalam biakan darah maupun gambaran klinis beserta faktor risiko yang berhubungan dengan derajat pneumonia yang disertai infeksi HIV/AIDS tidak dijelaskan lebih rinci. Jumlah sampel tidak terlalu besar sehingga memengaruhi hasil. Beberapa kelemahan tersebut menyebabkan penelitian kembali masih perlu dilakukan.

\section{Kesimpulan}

Kadar CD4 berbeda secara bermakna pada kelompok pneumonia berat dan sangat berat dan dapat memengaruhi derajat keparahan pneumonia, sedangkan jumlah leukosit tidak berbeda bermakna serta tidak memengaruhi derajat keparahan pneumonia pada anak. Kadar CD4 dapat digunakan sebagai prediktor untuk mengetahui derajat keparahan pneumonia pada anak dengan infeksi HIV.

\section{Daftar pustaka}

1. Yani F, Akib A, Supriyatno B, Setyanto D. Penyakit respiratorik pada anak dengan HIV. Sari Pediatri 2006;8:188-94.

2. Ghimire M, Bhattacharya S, Narain J. Pneumonia in south-east Asia region: public health perspective. Indian J 2012;135:459-68.

3. Evalina. Studi Deskriptif Infeksi HIV pada Anak di RSUP Adam Malik Medan. Sari Pediatri 2012;14:73-8.

4. Said M. Pneumonia. Dalam: Rahajoe NN, Supriyatno B, Setyanto DB, penyunting. Buku ajar respirologi anak. Edisi ke-1. Jakarta: Badan Penerbit IDAI;2008.h.350-65.

5. Zar H. Prevention of HIV-associated respiratory illness in children in developing countries: potential benefits. Tuberc Lung Dis Int J 2006;7:820-7.

6. Forsberg P. Pneumonia among hospitalized children aged 1-9 years-a prospective and retrospective study at a referral hospital in northern Tanzania. Pediatrics 2012;3;1-5.

7. Bill G, Kapogiannis, Minn M. Trends in Bacteremia in the pre- and post-highly active antiretroviral therapy era among HIV infected children in the US perinatal AIDS collaborative transmission study. Pediatrics 2007;1:1-6.

8. Ikeogu M, Wolf B, Mathe S. Pulmonary manifestations in HIV seropositivity and malnutrition in Zimbabwe. Arch Dis Child 1997;76:124-8.

9. Graham S, Coulter J, Gilks C. Pulmonary disese in HIVinfected African children. Int J Tuberc Lung Dis 2005;5:1223.

10. Rodroguez M, Fishman J. Prevention due to pneumocystis spp. in human immunodefi ciency virus-negative immunocompromised patients. Clin Microbiol Rev 2007;17:77082.

11. Hoser GA, Skirecki T, Zlotorowicz M, Zielinska-Borkowska U, Kawiak J. Absolute counts of peripheral blood leukocyte subpopulations in intraabdominal sepsis and pneumoniaderived sepsis: a pilot study. Folia Histochemica et Cytobiologica 2012;50:420-6. 
12. Williams AJ, Duong T, McNally LM. Pneumocystis carinii pneumonia and cytomegalovirus infection in children with vertically acquired HIV infection. AIDS 2010;15:335-9.

13. Ballin A, Osdachi A, Klivitsky A, Dalal I, Lishner M. Agerelated leukocyte and cytokine patterns in communityacquired bronchopneumonia. IMAJ 2006;8:388-90.

14. Furer V, Raveh D, Picard E, Goldberg S, Izbicki G. Absence of leukocytosis in bacteraemic pneumococcal pneumonia. Prim Care Respir 2011;20:276-81.

15. Jager CPC, Wever PC, Gemen EFA, Kuster R, GageldonkLafeber AB, Poll TV, dkk. The neutrophil-lymphocyte count ratio in patients with community-acquired pneumonia. Plos One. 2012;7:1-8.
16. Toikka P, Virkki R, Mertsola J, Ashora P, Eskola J, Ruuskanen O. Bacteremic pneumococcal pneumonia in children. Clin Infectious Dis 2009;29:568-72.

17. Kolling UK, Hansen F, Braun J, Rink L, Katus HA, Dalhoff $\mathrm{K}$. Leucocyte response and anti-inflammatory cytokines in community acquired pneumonia. Thorax 2011;56:121-5.

18. Singh RP, Kashyap AK, Puri S, Whig J. Pulmonary manifestations in HIV seropositive patients and their correlation with cd4 counts in a tertiary care centre of north India. JK Science India 2013;15:140-4.

19. Chakravarty J, Mehta H, Parekh A. Study on clinic epidemiological profile of HIV patients in Eastern India. J Assoc Physicians India 2006;54:854-7. 